Irena Selišnik

\title{
Zdenka Šadl: Umazano delo med stigmo in ponosom: Plačane gospodinjske delavke v Sloveniji
}

Ljubljana: Fakulteta za družbene vede, knjižna zbirka Ost/Fakulteta za družbene vede, 2009, 170 strani

$\mathrm{V}$ knjigi Umazano delo med stigmo in ponosom: Plačane gospodinjske delavke $\mathrm{v}$ Sloveniji se Zdenka Šadl v eni izmed redkih monografij, ki so doslej izšle na Slovenskem in govorijo o plačanem hišnem delu oziroma gospodinjskih pomočnicah, ukvarja $\mathrm{z}$ diskurzivno konstrukcijo umazanije, ki ji doda sociološko analizo družbenih razmerij v plačanem gospodinjskem delu. Z. Šadl teoretska izhodišča študije spretno vpne v interpretativne mreže intervjujev.

Znanstvena monografija dobro povzema in se navezuje na sodobne raziskave o plačanem hišnem delu, ki se soočajo s sodobnimi izzivi starajoče populacije, razpetostjo žensk med profesionalno kariero in gospodinjskim delom ter migracijami. Vendar pa se bolj kot na oblikovanje politik v Sloveniji in Evropi osredotoča na tradicijo humanističnih znanosti, konstrukcijo identitet ter sistemov neenakosti in dominacije. $\mathrm{V}$ teoretskih izhodiščih se avtorica navezuje na binarno nasprotje »čisto : umazano« in klasično teoretsko delo Mary Douglas Čisto in nevarno, ki je pokazalo, da je analiza umazanije stvar družbenega dojemanja in interpretacije. V razmerju med umazanim in čistim se skrivajo razmerja moči, odnosi med dominantnim in podrejenim, družbena neenakost. To bipolarnost lahko prepoznamo $\mathrm{v}$ razmerjih med spoloma, kjer ženske predstavljajo kontaminiranega drugega - umazanijo lahko predstavljajo na simbolni, pa tudi na fizični ravni. Tovrstno dihotomijo še vedno gojijo tudi sodobne medijske reprezentacije, ki ženskam na primer še vedno pripisujejo tradicionalno odgovornost za čiščenje doma. Avtorica se pri argumentaciji razlike med dobrimi in slabimi, čistimi in umazanimi ženskami nasloni tudi na koncept abjekta Julije Kristeve. $\mathrm{Z}$ njim »telesno umazanijo« poveže $\mathrm{z}$ zavrnjeno materinsko podobo v patriarhalnih družbah in tako s psihoanalitično interpretacijo doda novo globino. Razcepljena ženska podoba je projicirana tudi na druge družbene delitve, razred in raso. Ženske namreč niso enoten subjekt, v interpretativni kategoriji spola ne moremo brez drugim pomembnih razlik. Že omenjena dihotomija med umazanim in čistim se manifestira kot širše nasprotje med višjim in nižjim, superiornim in inferiornim, 
ter predstavlja konstitutiven dejavnik oblikovanja razredne, rasne in nacionalne diferenciacije. Potrditve teh ugotovitev srečamo v številnih zgodovinskih študijah o »domesticity« v viktorijanski družbi ali v Nemškem cesarstvu.

$\mathrm{V}$ tretjem poglavju se avtorica ukvarja s Hugesovim sociološkim konceptom umazanega dela, ki se nanaša na fizično, socialno ali moralno umazane naloge in poklice. Meje med vsemi tremi dimenzijami so zabrisane, navedene kategorije pa niso medsebojno izključujoče. To klasifikacijo umazanega dela sta kasneje nadgradila Ashfortova in Kreiner, ki sta dodala še dva kriterija za klasifikacijo nečistoče, pri čemer sta ločila dve ravni poklicnega ugleda. Prav čistilke in čistilci naj bi bili primer sodobne stigmatizacije in nizkega družbenega položaja, saj naj bi bilo nizko vrednotenje tega poklica tako trdno vsajeno $\mathrm{v}$ kolektivni spomin in socializacijski ustroj družb, da ga tudi razvoj industrijskih družb ni utegnil spremeniti. Nizek status gospodinjskega dela pojasnjujejo spolna določenost domačega dela, odsotnost posebnih ali razpoznavnih veščin, potrebnih za opravljanje dela, in vključenost umazanega kot polucije. Posledica vsega tega je nizka tržna vrednost tega dela, pa tudi pričakovana nevidnost, ki jo krepi neurejena pogodbena zaposlitvena ureditev.

V naslednjem poglavju nas avtorica z željo, da bi presegla simbolne sisteme in zajela prostorsko delitev gospodinjskega dela, konkretno organizacijo in družbena razmerja, še enkrat popelje do spolnih delitev. Moški ne čistijo, če pa se tega že lotijo, čistijo zaradi kurative (kopičenje nereda) in ne preventivno kot ženske, ki želijo preprečiti pojavljanje umazanije. Znotraj spolne delitve gospodinjskega dela obstaja delitev na umazana in čista dela, ki so tako $\mathrm{v}$ preteklosti kot danes razporejena na dve različni kategoriji žensk. Fizična in umazana gospodinjska opravila so v preteklosti, še pred izginjanjem stanu gospodinjske pomočnice in tehnološkimi spremembami, zdrsnila pod raven dostojnega ženskega dela, ki je pomenilo organizacijo gospodinjstva in upravljanje družinskega življenja. Približno v osemdesetih letih, ko naj bi v zahodnem svetu nastopilo veliko pomanjkanje gospodinjskih pomočnic, pa naj bi ženske skušale premostiti umazanijo in se umestiti na dobro stran dihotomije umazano : čisto s še večjo skrbjo za lastno telo, ki naj bi bilo urejeno, fit in čisto. Te ugotovitve bi se dalo prenesti tudi na slovenski prostor, kjer se $\mathrm{v}$ sedemdesetih letih $\mathrm{v}$ ženskih časopisih prav tako pojavljajo tožbe, da vlada pomanjkanje gospodinjskih pomočnic. To delo so namreč takrat prevzele mlajše upokojenke in vdove, proti koncu sedemdesetih let pa se kot gospodinjske pomočnice že začnejo zaposlovati priseljenke iz drugih delov Jugoslavije. Gospodinjsko delo se povsod po Evropi ponovno intenzivno premešča na ženske iz nižjih družbenih razredov in marginalnih skupin. Dogaja se prenos umazanega gospodinjskega dela iz uspešne profesionalke na drugo žensko, kar postaja uspešna strategija usklajevanja poklicnih in družinskih lastnosti. Plačano opravljanje umazanega dela učinkuje na identiteto in status obeh kategorij žensk. 
$\mathrm{V}$ naslednjih poglavjih $\mathrm{v}$ knjigi spregovorijo utišani in spregledani glasovi gospodinjskih pomočnic $\mathrm{v}$ Sloveniji. Avtorica se nasloni na feministično epistemologijo, izhaja iz standpoint teorije, kar pomeni, da je treba raziskovanje pričeti upoštevajoč položaj žensk, ter se odloči za stališča žensk, ki to delo opravljajo. Standpoint feministke visoko vrednotijo poglede pripadnikov marginaliziranih skupin in uporabljajo takšne raziskovalne postopke, s katerimi namenjajo pozornost in prostor alternativnim stališčem, ne pa družbeno prevladujočim pomenom. Avtorica se zaveda, da individualna izkušnja in njena interpretacija nista pot do edine resnice in da obstajajo številni pogledi in znanje, da ne obstaja le en sam »avtentičen pogled « na realnost. Toda v nasprotju s tem zavedanjem se ne odloči, da bi pogled delojemalk soočila s pogledom delodajalk. Angažirano se odloči, da podeli "politično moč« - moč poimenovanja in osmišljanja - le delojemalkam. Če je ena izmed osnovnih tez knjige, da je plačano gospodinjsko delo strategija osvobajanja privilegirane skupine žensk, bi te skoraj morale spregovoriti, morda pa je to predlog za eno izmed prihodnjih analiz.

Odločitev za intersekcijski pristop, ki vzame pod drobnogled preseke različnih sistemov gospodovanj, pa vendarle daje veliko zanimivih rezultatov. Avtorica v smislu sodobnih raziskav proučuje mikropolitiko $\mathrm{v}$ razmerjih med gospodinjsko pomočnico in delodajalko, njuno pogajanje, upor oziroma strategije gospodinjskih pomočnic v odnosu do gospodinj. V ospredje postavi visoko stopnjo personalizacije in emocionalnega naboja med gospodinjsko pomočnico in delodajalko ter $t$. $i$. familizacijo oziroma podružinjenje. Intimnost $\mathrm{v}$ tem odnosu deluje skoraj kot strateško sredstvo za uresničevanje konfliktnih interesov. Avtorica pa se osredotoči tudi na proces stigmatizacije žensk, ki opravljajo delo čistilke. Medtem ko nekatere to stigmo sprejmejo in jo ponotranjijo, ji druge nasprotujejo in se ji uprejo.

Z. Šadl tako pravzaprav spregovori o postavljanju meja v vsaj dveh kontekstih, $\mathrm{v}$ postavljanju meje $\mathrm{v}$ družbenih kategorijah $\mathrm{v}$ kontekstu razreda in nacionalnosti ter $\mathrm{v}$ postavljanju družbenih prostorskih meja $\mathrm{v}$ kontekstu intimnega/zasebnega in javnega. Med vsemi temi ločnicami pa se nahaja obilica pogajalskega dela v neenakih strukturnih okoliščinah, pa tudi številne majhne zmage in porazi, kar lahko prenesemo na marsikatere sodobne oblike prekarnega dela. 